\title{
"ESTADO ISLÁMICO: ¿AMENAZA PARA EL MUNDO O EL SURGIMIENTO DE UN NUEVO ESTADO?"
}

\section{"ISLAMIC STATE: ¿THE WORLD OR THREAT FOR THE EMERGENCE OF A NEW STATE?"}

\author{
Mgter. Prof. Fernando Ariel Bonfanti \\ Prof. Auxiliar cátedra Geografía Económica y Política General \\ Departamento de Geografía-Facultad de Humanidades-UNNE. \\ E-mail: fernandobonfanti@yahoo.com.ar
}

\section{Resumen}

El Estado Islámico, desconocido hasta hace poco tiempo, ha ingresado de manera abrupta y violenta en la actualidad geopolítica mundial durante el año 2014. Aprovechando las crisis existentes en Siria e Irak, tomó el control de vastas regiones y hoy dispone de numerosos recursos financieros. A diferencia de Al Qaeda (en la que tiene sus orígenes), ésta organización sunnita radical ha autoproclamado su propio Califato y partir de ahí su principal deseo es gobernar sobre todos los musulmanes del mundo, es decir que busca construir un amplio poder territorial, a partir de su severa interpretación del Islam y su violencia brutal contra los chiitas.

Palabras Claves: Estado - Geopolítica - Terrorismo - Oriente Medio - Islam

\section{Abstract}

The Islamic State, unknown until recently, has entered abruptly and violently in geopolitics today worldwide during 2014. Leveraging existing in Syria and Iraq crisis, took control of large areas and today has numerous financial resources. Unlike Al Qaeda (which has its origins), this radical Sunni organization has proclaimed their own caliphate and from there his main desire is to rule over all Muslims in the world, meaning that seeks to build a broad territorial power, from its harsh interpretation of Islam and its brutal violence against Shiites.

Keywords: State - Geopolitics - Terrorism - Middle East - Islam

\section{Introducción}

Desde el ocaso del siglo $X X$, el mundo no sólo viene experimentando drásticos cambios sociales, económicos, políticos y culturales (propios del avance de la globalización), sino también niveles de terror hasta entonces inusitados. La desintegración de la Unión Soviética y el fracaso del sistema comunista, hacían suponer que una nueva realidad económica globalizada brindaría oportunidades para el establecimiento de un dinamismo más renovado en las relaciones internacionales, que contribuyese a eliminar o reducir, las grandes diferencias existentes en el reparto de las riquezas entre unas zonas y otras del planeta, así como a propagar la idea de la democracia y a universalizar el respeto a los derechos humanos.

Sin embargo, la bipolaridad de antaño ha dado paso a un mundo unipolar, donde predomina, absolutamente, en el ámbito económico, político y militar la gran superpotencia vencedora de la etapa de la Guerra Fría: Estados Unidos. En este sentido, ese gran poderío norteamericano no va a ser contrarrestado por ningún otro poder global, ya que, la ONU, como organismo internacional, viene

Publicado en formato digital: Mgter. Prof. Fernando Ariel Bonfanti. ESTADO ISLÁMICO: ¿AMENAZA PARA EL MUNDO O EL SURGIMIENTO DE UN NUEVO ESTADO? Revista Geográfica Digital. IGUNNE. Facultad de Humanidades. UNNE. Año 13. № 25. Enero - Junio 2016. ISSN 1668-5180 Resistencia, Chaco. 
mostrándose anacrónica, endeble e inoperante en este "nuevo" orden mundial (Romero y Troyano, 2013).

El desorden y el caos generados por la globalización (Taibo, 2003) y la decidida política imperialista puesta en práctica por los sucesivos gobiernos norteamericanos, que culminó, incluso, con la invasión de un Estado soberano, como era Irak (Martín Muñoz, 2003; Ramonet, 2005), han ahondado las diferencias seculares entre los países desarrollados y los que se encuentran aún en vías de desarrollo, y han provocado, sobre todo, el uso habitual de uno de los métodos de protesta más dantescos y extremadamente violentos que existen, el terrorismo.

En este sentido, la creciente ola de terror que se ha expandido en los últimos años, fundamentalmente, desde el mundo árabe-musulmán hacia Occidente se debe a la propia trayectoria histórica de estos países (antes colonias), a sus estructuras políticas, sociales y económicas, y sobre todo al gran armazón ideológico y religioso predominante en dichas culturas.

En este sentido, el Estado Islámico, desconocido hasta hace poco tiempo, ha ingresado de manera abrupta y violenta en la actualidad geopolítica mundial. Aprovechando las crisis que acosan a Iraq y Siria, tomó el control de vastas regiones y hoy dispone de numerosos recursos financieros. A diferencia de Al Qaeda (en la que tiene sus orígenes), esta organización sunnita radical busca construir un amplio poder territorial. Al respecto, este artículo constituye un intento por comprender la situación que dio origen a este conflicto regional y es de sumo interés en el campo de la Geografía Política. El presente constituye un trabajo de carácter exploratorio, sostenido básicamente en la recopilación y análisis de bibliografía específica y de amplias fuentes de información dispersas en diferentes medios como diarios e internet. En este sentido y para lograr un mayor entendimiento de la cuestión, se proponen los siguientes objetivos:

- Indagar acerca del origen y la conformación del Estado Islámico.

- Identificar sus principales características y formas de financiamiento.

- Determinar sus principales objetivos en el nuevo orden internacional.

\section{Situación geopolítica regional}

El año 2014 constituyó el inicio de un nuevo período para el orden geopolítico mundial, pues en un breve lapso, un tiempo récord podría decirse, irrumpió en la escena un nuevo actor, el Estado Islámico (EI), que aprovechando la situación política de Siria e Irak creó allí una configuración inédita de las relaciones de fuerzas en Oriente Medio. Todos los medios de comunicación occidentales, asombrados, han descubierto a este ejército yihadista que comenzó a sembrar el terror con su violenta forma de proceder.

Sin embargo, había muchos signos precursores de este acontecimiento geopolítico de mayor importancia. Entre 2003 y 2008, durante la ocupación estadounidense, una guerra confesional entre sunnitas y chiitas ensangrentó Iraq. Fue un conflicto sin precedentes en la larga historia de las relaciones entre las dos principales comunidades musulmanas de este país; se tradujo en cientos de miles de muertos, en su gran mayoría chiitas, y en un proceso de fragmentación y "comunitarización" territorial del país. El caso de Bagdad es emblemático: esta metrópolis multiétnica y multiconfesional de siete millones de habitantes se convirtió en una ciudad herida y arruinada con una población $80 \%$ chiita. El poder y la visibilidad del Estado islámico aumentaron brutalmente con la extensión de sus ambiciones político-militares a la vecina Siria, también involucrada en una sangrienta guerra civil, consecuencia de la "primavera árabe" de 2011. La proclamación del Califato por el líder de la organización Abu Bakr al Baghdadi el 29 de junio de 2014, en un territorio que cabalga la frontera entre ambos países, ilustra la ambición proclamada de construir un verdadero Estado por quienes eran hasta hace poco un pequeño grupo salafista-yihadista entre muchos otros, entiéndase al salafismo como un movimiento sunnita rigorista y fundamentalista que promueve un supuesto retorno a los orígenes del islam (Luizard, 2015).

Puede decirse entonces que el Estado Islámico constituye un grupo terrorista insurgente, de naturaleza fundamentalista yihadista, que ha declarado la guerra contra todos los regímenes de la región y los poderes "infieles", demostrando así que se constituyó en poco tiempo en un fenómeno de

Publicado en formato digital: Mgter. Prof. Fernando Ariel Bonfanti. ESTADO ISLÁMICO: ¿AMENAZA PARA EL MUNDO O EL SURGIMIENTO DE UN NUEVO ESTADO? Revista Geográfica Digital. IGUNNE. Facultad de Humanidades. UNNE. Año 13. № 25. Enero - Junio 2016. ISSN 1668-5180 Resistencia, Chaco. 
dimensión global, que ha autoproclamado un califato y se asentó territorialmente en un amplio sector de Irak y Siria. Aunque técnicamente el grupo se organiza como un Estado no reconocido, controla de facto varias ciudades como Mosul, Faluya y Raqqa, siendo esta última considerada su capital (Martin, 2015).

Ahora bien, para poder entender mejor la cuestión debemos comprender que un "califato" es el sistema de gobierno sobre un territorio, establecido tras la muerte del profeta Mahoma en el año 632. Dirigido por un líder único denominado califa (sucesor en árabe) que concentra en sus manos todo el poder político y espiritual de acuerdo con la ley islámica ("sharia"), y que pretende abarcar a todos los musulmanes del área definida como califato. En ese sentido se constituye como una amenaza para los estados árabes constituidos en la zona (Hamon, 2015). El último califato que el mundo conoció fue el del Imperio Otomano, que cayó en 1923 tras concluir la Primera Guerra Mundial para convertirse luego en República de Turquía, país que luego de una reforma constitucional abolió el califato y comenzó su proceso de europeización, mediante el cual muchos estados árabes juzgaron a modo de traición. En forma inteligente, a mediados del siglo XX, la OTAN invitó a Turquía a adherirse a sus filas, lo que significó una jugada estratégica por parte de Occidente; ya que con Turquía de aliado, asegurarían la defensa colectiva de cualquiera de los Estados miembros de la organización.

\section{Los Orígenes del Estado Islámico}

Desde el comienzo del siglo XIX, y hasta fin de la Segunda Guerra mundial, Francia y Gran Bretaña han dominado Oriente; una vez finalizada esa guerra será América, en la figura de Estados Unidos la que domine la región (Beltrame, 2009). Mientras Gran Bretaña y Francia habían comenzado con la explotación de recursos petrolíferos, estratégicos y humanos en la región de Medio Oriente; EEUU se preparaba para desplegar su nuevo papel como potencia dominante luego de la guerra.

El inicio de la década del '90 deja improntas importantes en la región arábiga, pues en agosto de 1990 Irak, bajo el régimen del dictador Saddam Hussein invade Kuwait (el régimen iraquí consideraba históricamente a Kuwait como un distrito dentro de la provincia de Basora) fundamentalmente por necesidades e intereses económicos, así como razones políticas y estratégicas. Hussein aspiraba a lograr un mayor peso en la política árabe de la región y esto era la deuda que le había dejado su larga guerra de 8 años con Irán, y cuyo principal deudor era Kuwait (Beltrame, 2009).

Efectivamente, la Guerra del Golfo de 1991 ha constituido un punto de inflexión en la situación política — regional y mundial— pues tras varios meses críticos la problemática del Golfo había traspasado los límites regionales y se había instalado como la cuestión más importante de la escena mundial. Estados Unidos, con presencia militar consolidada en la zona, exigió la inmediata retirada iraquí. El Consejo de Seguridad de la ONU autorizó el uso de la fuerza para que Irak abandonara Kuwait; de este modo, esta guerra — avalada por la legitimidad internacional— supuso un cambio crucial en las relaciones de poder: Estados Unidos asumía el rol de única potencia hegemónica e indiscutida potencia militar (Beltrame, 2009).

El "Nuevo Orden Mundial" se caracterizará por el rol geoestratégico del petróleo y el control de los recursos energéticos, lo cual se evidenciará a través del dominio estadounidense como superpotencia militar.

Con todo este conflicto, Saddam Hussein logró situar su nombre como el principal enemigo a batir y gran desestabilizador de la paz mundial. En paralelo y ya desaparecida la Unión Soviética, el Islam queda señalado como la amenaza más peligrosa para Occidente (Brieger, 2006).

El ataque terrorista que derribó la Torres Gemelas de Nueva York, el 11 de septiembre de 2001 (con gran dureza y planificación) puso a la seguridad como el tema prioritario en detrimento de los asuntos económicos, culturales y sociales, y ese gran poder que ostentaban los norteamericanos se venía abajo. Estados Unidos al verse obligado a buscar culpables puso el dedo acusador sobre el mundo árabe. Emergió entonces la figura del terrorista Osama Bin Laden (líder de Al-Qaeda y autor ideológico de los atentados) para convertirse de inmediato en el nuevo enemigo de Occidente,

Publicado en formato digital: Mgter. Prof. Fernando Ariel Bonfanti. ESTADO ISLÁMICO: ¿AMENAZA PARA EL MUNDO O EL SURGIMIENTO DE UN NUEVO ESTADO? Revista Geográfica Digital. IGUNNE. Facultad de Humanidades. UNNE. Año 13. No 25. Enero - Junio 2016. ISSN 1668-5180 Resistencia, Chaco. 
haciendo que la lucha contra el terrorismo mundial sea el principal objetivo. Tan pronto fueron las represalias que un mes después de los atentados, Estados Unidos lanzó su poderío militar contra Afganistán para derribar su régimen talibán, que supuestamente daba resguardo a Bin Laden, quien de a poco se convirtió en el responsable directo de la insurgencia de grupos radicales, que alimentaron el odio y provocaron un rechazo generalizado en el mundo árabe hacia la principal potencia del mundo. El triunfo en la guerra de Afganistán derrocó del poder a los talibanes y restauraron un gobierno democrático algo confuso, situación que ha beneficiado a Al Qaeda.

El dominio que se pretendía ejercer en esta nación, siempre tuvo ribetes de importancia geopolítica y estratégica, ya que permitió monitorear de cerca todas las potencias nucleares de la región: China, Rusia, Irán, Pakistán y Corea del Norte ante un posible ataque a la nación occidental. Posteriormente y luego del daño ocasionado en Afganistán, en el año 2003 (como el objetivo era asegurar la paz en el mundo y acabar con las conexiones terroristas), el objetivo principal contra el terrorismo recae en Irak.

Se produce la invasión a ese país con una coalición encabezada por Estados Unidos, que contaba con el respaldo de Gran Bretaña, Polonia, Portugal, Italia, Dinamarca y Australia, entre otros países, cuya justificación concreta era la vinculación que allí existía entre la red Al Qaeda con el régimen de Saddam Hussein. La misión principal era encontrar e inutilizar las armas de destrucción masiva con las que contaba Saddam y, al mismo tiempo, liberar al pueblo iraquí del régimen opresor del dictador (Beltrame, 2009).

La organización terrorista fue parte de la resistencia a la invasión estadounidense en Irak, en el año 2004 juraron lealtad a Osama Bin Laden y pasaron a llamarse "Al-Qaeda en Irak", constituyendo ésta la primera etapa del grupo en territorio iraquí, como se aprecia en el en Mapa $\mathrm{N}^{\circ}$ 1.

Mapa № 1

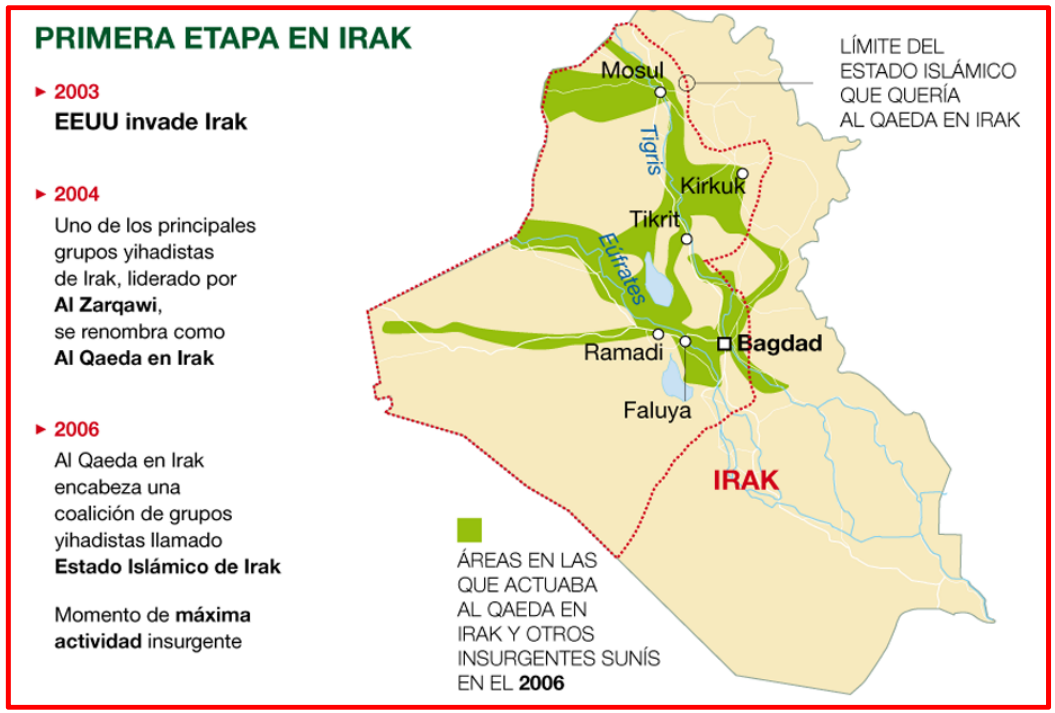

Fuente: Radiografía del Estado Islámico. En: http://www.elperiodico.com/es/graficos/internacional/radiografia-delestado-islamico-5210/

La captura de Saddam Hussein en el año 2003 y su posterior ejecución en 2006 fueron motivo de portada en todos los medios de comunicación mundiales. Pero para entonces Irak ya era un lugar arrasado por los bombardeos estadounidenses. Poco o nada quedaba del régimen anterior. Numerosos grupos terroristas se infiltraron en la resistencia iraquí, y los problemas de seguridad obligaron a la coalición a replantear varias veces sus estrategias de intervención. La reconstrucción

Publicado en formato digital: Mgter. Prof. Fernando Ariel Bonfanti. ESTADO ISLÁMICO: ¿AMENAZA PARA EL MUNDO O EL SURGIMIENTO DE UN NUEVO ESTADO? Revista Geográfica Digital. IGUNNE. Facultad de Humanidades. UNNE. Año 13. N No 25. Enero - Junio 2016. ISSN 1668-5180 Resistencia, Chaco. 
del país y la transición a la democracia iban a tardar más de lo esperado. Las armas de destrucción masiva nunca aparecieron, los tesoros arqueológicos del país fueron saqueados y el número de víctimas civiles y heridos no dejaba de aumentar (Cfr. Beltrame, 2009).

Como se aprecia, el ejército iraquí fue desmantelado en su mayoría y nuevas fuerzas de seguridad fueron creadas. La guerra en Irak produjo finalmente un estado dominado por una mayoría chiita que eligió al primer ministro Nuri al-Maliki, a quien la población sunita ha acusado de gobernar con una agenda sectaria que ignoraba las necesidades de las otras comunidades. Paralelamente, los kurdos lograron un significativo nivel de autonomía en el norte del país (Martín, 2015).

Teniendo en cuenta todo lo antedicho puede decirse que, en términos estrictos, el Estado Islámico es la prolongación cismática de la organización Al-Qaeda. Fue el conocido Abu Musab AlZarqaui, muerto en 2006 en un bombardeo estadounidense, el que reunió contra la ocupación toda una serie de grupos yihadistas, inicialmente asociados a Al-Qaeda, que fueron alejándose cada vez más de Osama Bin Laden. El líder de Al-Qaeda era considerado blando y poco conocedor del terreno y se volvió cada vez más incapaz de mantener la disciplina en sus filas. A mediados del año 2006 nace el Estado Islámico de Irak, embrión del Estado Islámico, y a fines de la década es prácticamente independiente de la franquicia original. Un año antes se había unido al grupo de Al Zarqaui el hoy autodenominado primer Califa del Estado Islámico, Abu Bakr Al-Baghdadi, un clérigo nacido en Faluya y encarcelado durante un año, tras la invasión estadounidense, por las fuerzas de ocupación. Es la cárcel, y no la mezquita, en efecto, la verdadera escuela de los yihadistas radicales, tanto en Irak y Siria como en Europa (Alba Rico, 2015).

\section{Un acontecimiento inesperado que reforzó a esta organización}

La mutación que se ha dado en el seno del Estado islámico no puede explicarse sólo desde su propia historia, al ritmo de la ocupación estadounidense de Irak. A fines de 2010 ocurre algo inesperadamente normal, primero en Túnez y después en toda la región, desde Mauritania hasta el Golfo: los pueblos de la zona -árabes y no-, congelados desde el fin de la Guerra Fría, se deshielan de pronto y tratan de sacudirse el cepo de las dictaduras bajo las que vivían desde 1945. Las mal llamadas "primaveras árabes", en efecto, no sólo consiguieron derrocar a cuatro dictadores en pocos meses (Ben Ali, Mubarak, Ali Saleh y Gadafi) y activar intifadas locales que amenazaron el humillante "orden establecido" regional sino que, sobre todo, desmintieron el imaginario que asociaba esta zona del mundo a la pasividad o al fanatismo; millones de jóvenes ocuparon las plazas, en un modernísimo movimiento copiado en Madrid y Nueva York, para pedir democracia, justicia social y soberanía económica, tres demandas sintetizadas en la expresión "dignidad" (karama). Durante unos pocos meses, este hervor popular dejó realmente fuera de juego a las tres fuerzas mellizas que en las últimas décadas habían conferido "estabilidad" a Medio Oriente y al Norte de África: las dictaduras, las intervenciones extranjeras y el yihadismo radical (Alba Rico, 2015). Los pueblos de la región se rebelaron contra estas tres fuerzas haciendo que junto con los dictadores y la intervención colonial, cayera también el apoyo a Al-Qaeda.

Así entonces, la reaparición de este movimiento, con su nuevo formato, ha sido el resultado del fracaso de las revoluciones democráticas; pues si la primavera árabe se levanta contra las tres fuerzas mellizas, éstas vuelven ahora con fuerza renovada tras el triunfo de las distintas contrarrevoluciones.

Vuelven las intervenciones extranjeras, ahora multinacionales y a veces contradictorias (en Libia, la primera, freno de la revolución, en Yemen, en Bahrein, en Siria, donde luchan por delegación al menos ocho naciones), acompañadas de guerras civiles y violencias sectarias. Vuelven las dictaduras: la siria, que nunca se fue, o la egipcia, aun más brutal que la de Mubarak, por no hablar de todas las que se mantienen, desde Arabia Saudita hasta Argelia, de Jordania a Marruecos, endurecidas tras las malogradas primaveras (Alba Rico, 2015). Y por supuesto también vuelve el yihadismo, al que los jóvenes dieron la espalda en 2011 junto a las dictaduras por ellos derrocadas.

El Estado islámico es una contrarrevolución porque es una revolución en sentido contrario, que involucra a la misma gente que lo descartó cuatro años antes. El caos y la dictadura son el

Publicado en formato digital: Mgter. Prof. Fernando Ariel Bonfanti. ESTADO ISLÁMICO: ¿AMENAZA PARA EL MUNDO O EL SURGIMIENTO DE UN NUEVO ESTADO? Revista Geográfica Digital. IGUNNE. Facultad de Humanidades. UNNE. Año 13. № 25. Enero - Junio 2016. ISSN 1668-5180 Resistencia, Chaco. 
fermento natural del yihadismo y no es raro, por tanto, que creciera primero en el Irak ocupado y que ahora parasite el caos que generaron en Siria los crímenes del régimen contra la justísima revolución y la subsiguiente militarización del conflicto; militarización explotada enseguida desde el exterior por las fuerzas más reaccionarias de la región. Que se haya asentado territorialmente en Irak y en Siria no es una casualidad, pues son estos dos países los que han vivido un proceso similar -aunque de distinta genealogía- de descomposición y violencia. Pero en todo caso la implantación territorial del Estado islámico, su apoyo "internacionalista" y su modernísimo nihilismo mediático son inseparables del fracaso de las intifadas democráticas y del retorno de los imperialismos y las dictaduras que el EI mismo contribuye a alimentar. (Alba Rico, 2015)

Bajo el liderazgo de Abu Bakr al-Baghdadi, cabecilla de la organización desde 2010, el grupo supo aprovechar la coyuntura de la Guerra Civil Siria y expandirse por gran parte del territorio del país, declarándose en abril de 2013 con el nombre de ISIL (Estado Islámico de Irak y el Levante), también se utilizan las siglas ISIS, provenientes del nombre en árabe "Islamic State of Iraq and alSham", donde Sham hace referencia al Levante o a la Gran Siria. Al conquistar el territorio de una gran parte de Irak y Siria en un período que se extendió desde la segunda mitad de 2013 hasta la primera mitad de 2014, Al-Qaeda rompe relaciones con el ISIL, por estar en desacuerdo con su accionar sanguinario y violento, desapareciendo de este modo las palabras "Irak" y "Sham" del nombre oficial del grupo, pasando a denominarse simplemente Estado Islámico (EI) a partir de junio de 2014 (Ver Mapa $N^{\circ}$ 2)

A mediados de 2014, el avance de los militantes del autoproclamado estado Islámico logró que Irán y Estados Unidos dialogaran por primera vez sobre la situación en Irak no como enemigos, sino como poderes regionales preocupados por sus intereses en la región.

Mapa No 2

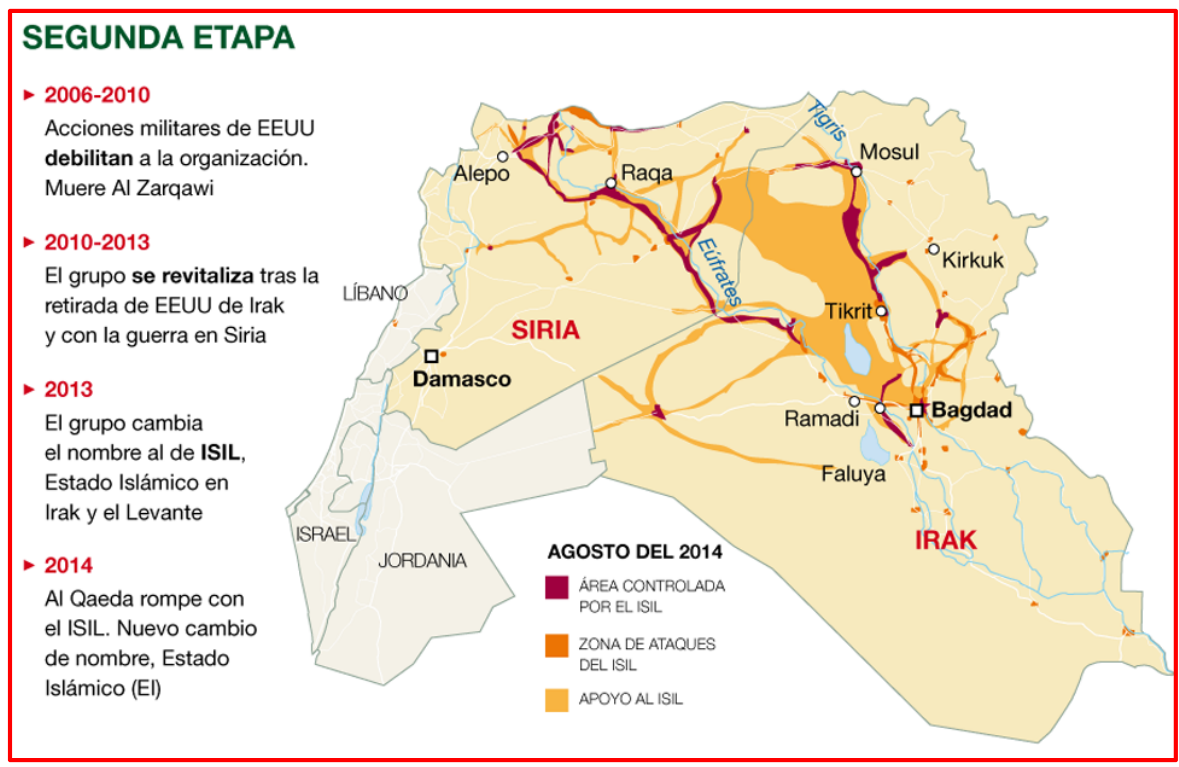

Fuente: Radiografía del Estado Islámico. En: http://www.elperiodico.com/es/graficos/internacional/radiografia-delestado-islamico-5210/

En el año 2014 se han autoproclamado su propio Califato y partir de ahí su principal deseo es gobernar sobre todos los musulmanes del mundo, pues su objetivo declarado es expandirse por Jordania, Israel, Palestina, Líbano, Kuwait, Turquía y Chipre. La organización se caracteriza por su

Publicado en formato digital: Mgter. Prof. Fernando Ariel Bonfanti. ESTADO ISLÁMICO: ¿AMENAZA PARA EL MUNDO O EL SURGIMIENTO DE UN NUEVO ESTADO? Revista Geográfica Digital. IGUNNE. Facultad de Humanidades. UNNE. Año 13. № 25. Enero - Junio 2016. ISSN 1668-5180 Resistencia, Chaco. 
severa interpretación del Islam y su violencia brutal contra los chiitas -al ser sus miembros de fe suní- (Martín, 2015). Asimismo, reparten dinero y comida entre la población, ganan adeptos en el extranjero, consiguen victorias sobre ejércitos profesionales, persiguen y asesinan a etnias minoritarias, se han enemistado con la propia al-Qaeda y no responden ante nadie (Pérez Ventura, 2014).

Desde la proclamación de su califato islámico, los yihadistas sunnitas del Estado Islámico, con una administración y recursos financieros propios, han ocupado y controlado un territorio que, entre en el noroeste de Irak y noreste de Siria, posee una superficie de aproximadamente $90.000 \mathrm{~km}^{2}$, un área del tamaño de Italia (Ver Mapa $\mathrm{N}^{\circ} 3$ ) y donde viven cerca de 8 millones de personas mayoritariamente sunitas.

\section{Mapa $N^{0} 3$}

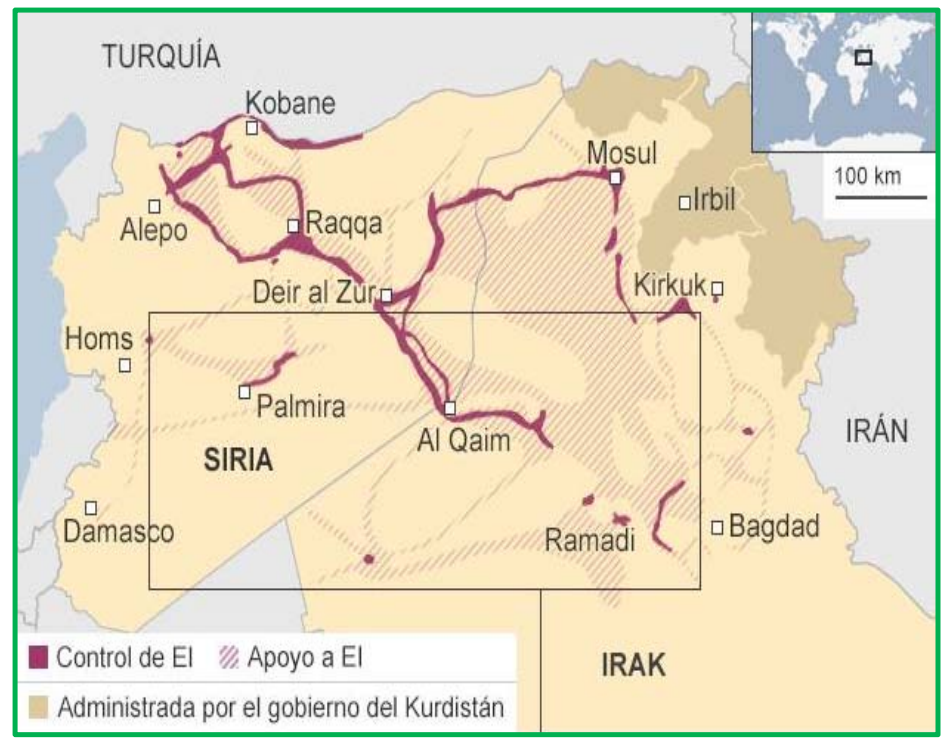

Fuente: BBC periódico de noticias. Instituto para el estudio de la guerra, 20 de mayo de 2015.

En este mapa del año 2015 se aprecia el área ocupada efectivamente por el Estado islámico (El) y otras en las que recibe apoyo. Según se observa, uno de sus principales opositores continúan siendo las fuerzas kurdas, que ocupan el nordeste de Irak.

Desde el mismo momento en que ISIS (como también se lo llama) ocupó territorios de Irak y Siria, el grupo se propuso llevar adelante tres líneas de acción paralelas. En primer lugar incitar al conflicto regional con ataques en Irak y Siria, para ocupar cada vez más territorios; en segundo lugar, construir relaciones con grupos yihadistas que puedan llevar a cabo operaciones militares en todo el Oriente Medio y el Norte de África; y por último, inspirar y/o ayudar a seguidores de la causa para que realicen ataques en Occidente.

A continuación puede observarse en un mapa los territorios que ha ganado y perdido el Estado Islámico durante el año 2015. 
Mapa $N^{\circ} 4$

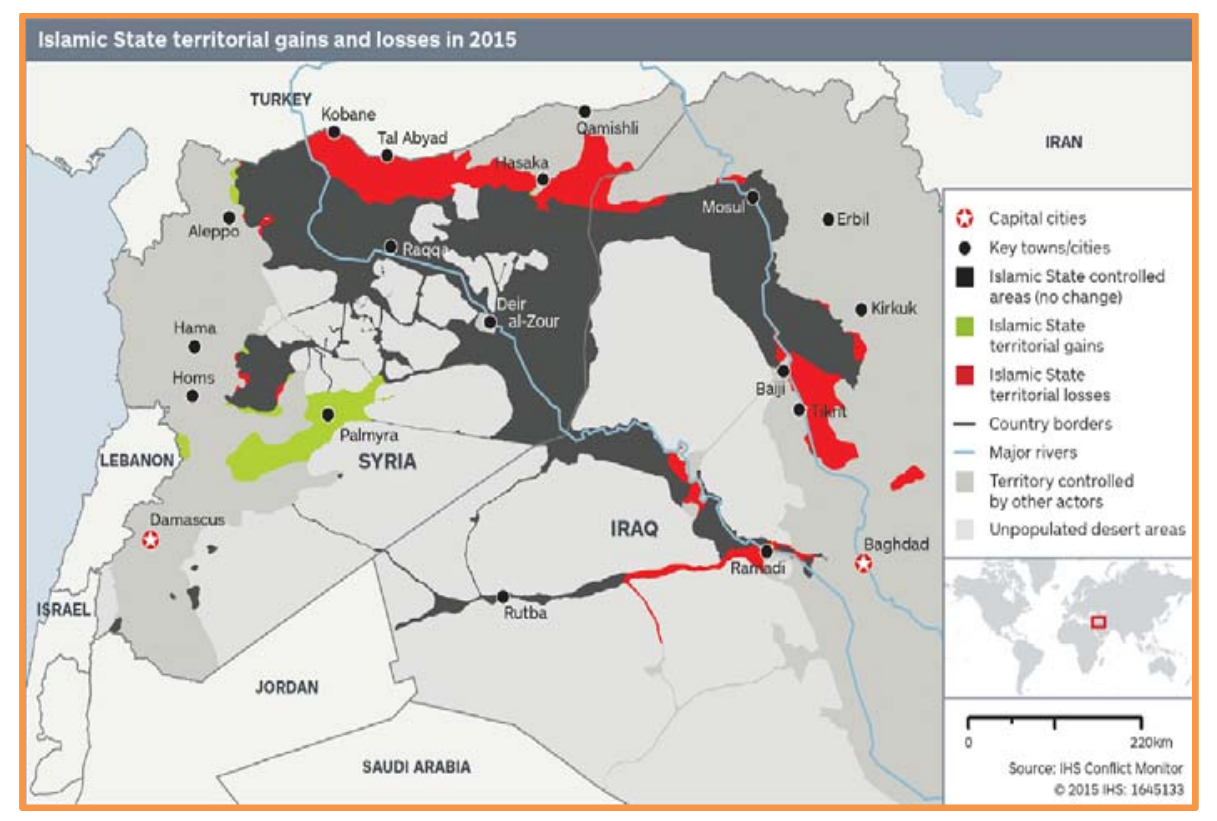

Fuente: Mapa elaborado por la revista militar británico-estadounidense IHS Jane's.

En el Mapa No 4, publicado hacia fines del año 2015 por la revista militar británicoestadounidense IHS Jane's, puede observarse con un color gris el área que controla el Estado Islámico entre Siria e Irak. Se puede deducir también que el 2015 no ha sido un buen año para ISIS, ya que su milicia terrorista perdió cerca del $14 \%$ del territorio que dominaba tiempo atrás (color rojo en el mapa), siendo su principal enemigo la milicia separatista kurda, que ha visto triplicar los territorios bajo su control y no la coalición liderada por Estados Unidos ni la de Rusia que inició bombardeos aéreos en octubre como puede pensarse.

El autoproclamado califato, según la revista IHS Jane's dejó de tener dominio sobre unos $12.800 \mathrm{~km}^{2}$, y actualmente controla cerca de $78.000 \mathrm{~km}^{2}$.

Dentro de los territorios que pudo conquistar (color verde en el mapa) está la ciudad de Palmira (Siria) y toda su región circundante, así como también una pequeña porción muy próxima al Líbano. En cambio, gran parte del territorio que perdió El (color rojo) en manos de los kurdos se encuentra en el norte de Siria, en la frontera con Turquía, mientras que en Irak, dejó de controlar la ciudad de Tikrit y la de Baiyi, donde está la mayor refinería de petróleo del país, así como una parte de la importante carretera que une Mosul, en el norte de Irak, con Raqqa, lo que les dificulta ahora el transporte de bienes y combatientes.

De acuerdo a esto, los kurdos se constituyen en un principio de obstáculo para el El, más que un objetivo en sí mismos. Los sirios kurdos dominan un grupo llamado Fuerzas Democráticas sirias, una coalición de combatientes kurdos y árabes que luchan contra los yihadistas en el nordeste de Siria. Si a esto se le suma la llevada adelante por las fuerzas aliadas lideradas por Estados Unidos y la reciente incursión de Rusia (aliado histórico del gobierno del presidente Bashar al-Assad en Siria), en conjunto buscan frenar -cada uno con sus intereses- el avance terrorista de esta organización.

\section{El Estado Islámico es verdaderamente un estado?}

Desde el punto de vista geográfico es sabido que para que exista un estado, es necesario la presencia de algunos elementos fundamentales como: territorio (donde el estado puede ejercer su

Publicado en formato digital: Mgter. Prof. Fernando Ariel Bonfanti. ESTADO ISLÁMICO: ¿AMENAZA PARA EL MUNDO O EL SURGIMIENTO DE UN NUEVO ESTADO? Revista Geográfica Digital. IGUNNE. Facultad de Humanidades. UNNE. Año 13. № 25. Enero - Junio 2016. ISSN 1668-5180 Resistencia, Chaco. 
soberanía), pueblo (está formado por toda la población que habita ese territorio) y un sistema jurídico que regule la conducta de cada uno de sus individuos.

Ahora bien, teniendo en cuenta estos elementos, el Estado Islámico posee todas las características mencionadas anteriormente para ser en verdad un estado? ¿Se comporta como tal? ¿Lo reconocen los otros países? ¿Ejerce las obligaciones que se les suponen? ¿Reconocen sus ciudadanos a los salafistas como sus soberanos gobernantes? ¿Es viable hacer la guerra mientras se construye una nación? Estas cuestiones no son menores ya que el Estado Islámico posee características que lo hacen diferente a cualquier otra organización del estilo de Al-Qaeda que se esfuerza en hacer cumplir la religión musulmana en forma estricta. El Estado Islámico no es otro grupo terrorista que golpea y se esconde. Tiene un territorio que ya ha ocupado, tiene un sistema de gobierno (Califato) con toda una estructura administrativa, tiene una población bajo su control, posee una ley, tiene sus propios ingresos y, más importante todavía, tiene la determinación de no ser mandado por nadie. Sin embargo, el Califato también posee los enemigos más poderosos de la región y del mundo. Los Estados Unidos e Irán han forjado una singular alianza para poner fin a su expansión. Pero esto no tiene porqué ser un impedimento para desarrollar un proyecto de construcción estatal.

Desde la proclamación del califato, se han consolidado en muy poco tiempo, no son simples terroristas sino un grupo con vocación de gobernar, esa es su voluntad y su poder. Tomaron la ciudad de Mosul sin disparar. Si pierden o ganan posiciones en los combates con los ejércitos sirio e iraquí es siempre a cientos de kilómetros de Mosul. Esa es su capital y allí están tranquilos. Evidentemente se consolidan, puede decirse que constituyen un protoestado; su aspiración es gestionar un territorio y de hecho lo hace. Es un estado dentro de un estado, como Hizbulah en el Líbano; pero en este caso en Iraq (Martín, 2015).

La principal diferencia entre el Estado Islámico y Al Qaeda radica en que, el primero es un grupo iraquí, aunque también haya sirios en los puestos de mando; el segundo tenía una naturaleza más global, con dirigentes saudíes, egipcios, iraquíes... El Estado Islámico tiene vocación de estado y Al Qaeda nunca ha buscado una estructura así, era algo así como una ideología. El Estado islámico tiene una idea más global: recuperar todos los territorios que alguna vez ocupó el Islam, y para ello es muy pragmático y el primer paso para llegar a esa idea es tener un territorio que gestionar y desde el cual puedan extenderse, y eso es lo que están haciendo con éxito. Sintetizando, Al Qaeda era la idea, el Estado Islámico la pone en práctica. (Cfr. Martín, 2015)

\section{Forma de operar en el territorio}

Una de las formas de operar que tiene este grupo es a través de impactantes atentados y asesinatos que cometen sus milicianos, desde decapitaciones y degüellos hasta crucifixiones, matanza de mujeres y niños y destrucción arqueológica. Todo esto lo llevan adelante a través de cuidadosos montajes cinematográficos, presentados como si se tratase de un documental o una película de arte y ensayo, cuyas imágenes son difundidas por los medios de comunicación hacia la opinión pública occidental, generando miedo en gran parte de la población. Pero además de intimidar al enemigo también buscan lograr con eso el reclutamiento de posibles adeptos. La muerte tiene aquí una dimensión cinematográfica y publicitaria que atrae a miles de jóvenes rebeldes "cansados de la civilización" y la hipocresía y que encuentran en el Estado Islámico una protesta total contra la "moral burguesa" (Rico, 2015).

Tras cometer atroces asesinados y sangrientos atentados, la organización de Estado Islámico publica informes anuales con todo tipo de datos y detalles técnicos. Esto, más que una anécdota, revela que Estado Islámico es mucho más que un simple grupo terrorista. Tiene una estructura, una gestión, una serie de 'empleados' que trabajan en distintas áreas... No sólo comenten atentados, sino que trabajan continuamente en la producción de material para difundir su actividad. Si hay oferta de este tipo de materiales es por una razón: hay gente que los demanda (Pérez Ventura, 2014)

Además de esta llamativa labor, el Estado Islámico ha comprendido que en el Siglo XXI la guerra no sólo se hace en el campo de batalla, sino también en las redes sociales. El grupo tiene un "ejército" de simpatizantes y varios perfiles desde donde informa de la actualidad de sus acciones y

Publicado en formato digital: Mgter. Prof. Fernando Ariel Bonfanti. ESTADO ISLÁMICO: ¿AMENAZA PARA EL MUNDO O EL SURGIMIENTO DE UN NUEVO ESTADO? Revista Geográfica Digital. IGUNNE. Facultad de Humanidades. UNNE. Año 13. № 25. Enero - Junio 2016. ISSN 1668-5180 Resistencia, Chaco. 
exalta el espíritu wahhabista. Con la utilización de hashtags y otras técnicas, Estado Islámico también está muy presente en Twitter. Es curioso cómo un grupo, aunque sea terrorista, consigue repercusión y se comunica con la gente en el mundo actual (Pérez Ventura, 2014). Se evidencia con todo esto, que poseen una asombrosa capacidad de organización, por el territorio que han conquistado, por la estructura interna del grupo, y por el gran uso de las técnicas de comunicación y publicidad, puede decirse que Estado Islámico es mucho más que un grupo terrorista, es una organización completamente autárquico que mueve varios millones de dólares procedentes del asalto de bancos y venta de petróleo a Turquía, al régimen sirio y a China (porque también controlan yacimientos petrolíferos), y que tiene establecida una clara jerarquía entre sus líderes, ya que además del autoproclamado califa al-Baghdadi, el grupo tiene un gabinete de ministros, un consejo de guerra y una serie de gobernadores en las provincias que controla.

Parte del éxito de ISIS se debe a su estrategia política. Busca arraigarse duraderamente a nivel local a través de dos mecanismos uno policial y otro administrativo. El mecanismo policial religioso ejerce el control de las poblaciones, actuando con terror y haciendo cumplir en forma estricta la "sharia" o ley islámica: mujeres obligadas a cumplir estrictas normas de vestir, interdicción del tabaco y alcohol, ejecuciones sumarias, decapitaciones y crucifixiones para los oponentes, etc. Muchos analistas internacionales los comparan con los nazis, ya que ofrecen seguridad absoluta a la población a cambio de su sometimiento incondicional. Por otra parte, su gestión administrativa es eficiente y muy parecida a la de un Estado, ya que al recaudar impuestos, construye infraestructuras como hospitales y abre escuelas para educar a sus ciudadanos. Según Jean Pierre Luizard (2015) la clave es que "ISIS no se impone como una fuerza de ocupación" sino que administra a la manera de un Estado el territorio que controla. "Su estrategia de implantación a largo plazo radica en la restitución del poder local a actores locales que tiene bajo su control. Se basa en las estructuras administrativas y civiles existentes".

\section{Rol desempeñado por Estados Unidos en la conformación del Estado Islámico}

El historiador Robert Freeman afirma que la principal potencia militar del mundo, Estados Unidos, ha jugado un rol central en la creación del Estado islámico, creación que ha pasado por tres etapas importantes:

La primera etapa de la creación del grupo Estado Islámico se produjo durante la guerra de Irak y el derrocamiento del gobierno secular de Sadam Husein. Según Freeman, el régimen dictatorial de Husein fue "corrupto, pero estabilizador": durante su gobierno Al Qaeda no existía dentro de Irak, y el Estado Islámico tiene su origen precisamente en Al Qaeda. Además, EE.UU. dejó el poder en Irak - la mitad de la población del país es sunita- en manos de un gobierno chí́ta. El hecho de que el ejército iraquí y kurdo hayan sido derrotados por el Estado Islámico se debe a que los sunitas prefirieron aliarse con sus correligionarios yihadistas en lugar de hacerlo con sus "adversarios religiosos" chítas.

La segunda etapa se dio en la campaña contra el Gobierno de Bashar al Assad en Siria. El presidente sirio contaba con una fuerza que durante muchos años mantuvo en "paz relativa" a un conjunto de sectas religiosas dentro de su país. Para modificar esa situación, en varias ocasiones E.E.U.U. ayudó a los "precursores" del Estado Islámico en territorio sirio -entre los cuales estuvo el Frente al-Nusra- con el fin de desestabilizar al Gobierno de Bashar al Assad.

La tercera etapa de la formación del Estado Islámico tuvo lugar cuando "EE.UU. organizó a Arabia Saudita y Turquía para que financiaran y apoyaran a los rebeldes en Siria", quienes, según Freeman, ya eran un "proto-Estado Islámico". Con respecto a Arabia Saudita puede decirse que profesa principalmente el wahhabismo, una de las versiones antioccidentales más agresivas del Islam.

Pese a haber creado al Estado Islámico, EE.UU. muestra sus fragilidades a la hora de combatirlo debido a la ausencia de una "estrategia coherente". En este sentido, los "rebeldes moderados" que EE.UU. entrenaba en Siria contra Assad ahora se niegan a luchar contra el Estado Islámico, algo que, según el Freeman, no es sorprendente, ya que estos rebeldes entregaban a los yihadistas armas suministradas por EE.UU. En este sentido, las fuerzas más capaces de vencer al

Publicado en formato digital: Mgter. Prof. Fernando Ariel Bonfanti. ESTADO ISLÁMICO: ¿AMENAZA PARA EL MUNDO O EL SURGIMIENTO DE UN NUEVO ESTADO? Revista Geográfica Digital. IGUNNE. Facultad de Humanidades. UNNE. Año 13. № 25. Enero - Junio 2016. ISSN 1668-5180 Resistencia, Chaco. 
Estado Islámico a corto plazo son Rusia, Siria e Irán, pero EE.UU. prefiere ver como la situación de los terroristas se agrava antes que verlos vencidos por los propios enemigos de EE.UU. A su vez Turquía persigue sus propios intereses en la región, demostrado en el hecho de que han colaborado financieramente con el Estado Islámico y no participaron de los ataques aéreos realizados por EE.UU. y sus aliados contra posiciones del ISIS en Siria. Afirma Freeman que, al gobierno turco no le interesa que los kurdos que combaten contra el Estado Islámico sean fuertes, ya que en caso de que se acabara formando un estado kurdo, una parte suya sería hoy parte del territorio de Turquía.

\section{Objetivos del Estado islámico}

Aunque llevan años actuando en el territorio de Irak, los medios de comunicación no se percataron de la existencia del grupo hasta mediados de 2014, cuando Al-Baghdadi proclamó el nuevo Califato Islámico e hizo públicas sus intenciones: conquistar bajo su mando todo el mundo musulmán.

El objetivo principal de Estado islámico es reestablecer un califato global regido por la Sharía (ley islámica) y que esté acompañado por una interpretación del Islam desde el wahhabismo más extremista -el wahhabismo es una corriente religiosa de la rama mayoritaria del Islam que aplica la ley islámica con rigor y tiene el deseo de expansión por el mundo-. De esta manera, el grupo Estado Islámico tiene una importante base religiosa y ética sobre la que apoyar sus ideas y acciones.

Los movimientos que ha llevado a cabo, propios de un ejército militar profesional, la organización del grupo y la gestión que están llevando del territorio indican que este nuevo enemigo está preparado para aguantar durante mucho tiempo. Estado Islámico pretende acabar con el resultado de los Acuerdos Sykes-Picot, que derivaron en la actual división territorial de Oriente. Debido a estos acuerdos, las fronteras en esta región son las que son. Así lo decidieron entre Reino Unido, Francia y Rusia en el año 1916, para repartirse el control del territorio. Por el rechazo a Occidente y por el deseo de unir a todo el mundo musulmán en un mismo califato, El quiere borrar las fronteras entre los países; actualmente ya lo ha conseguido entre Siria e Irak.

Defensores de la población suní, los yihadistas del Estado Islámico han marcado objetivos muy claros: los chíes, los cristianos, las minorías religiosas y los gobiernos de prácticamente todos los países. Desde Estados Unidos hasta Irán, pasando por Bachar al-Asad, Netanyahu, al-Maliki. Su extremismo se evidencia en situaciones como la vivida en Siria, donde el El está luchando contra el Gobierno de Al-Assad y al mismo tiempo contra los grupos rebeldes (Pérez Ventura, 2014)

Según el Grupo Soufan -citado en el periódico "The Washington Post"-, que ofrece servicios estratégicos de inteligencia de seguridad a gobiernos y organizaciones multinacionales, además de la exitosa captura de las ciudades de Ramadi en Irak y Palmira en Siria, el Estado Islámico (ya ha establecido 20 provincias en su territorio) también ha formado 10 redes fuera de los dos países (denominados valiatos o provincias), aunque se trata solamente de los bastiones públicamente reconocidos por ISIS como parte de su creciente califato.

Estas redes islamistas -tres en Libia, dos en Arabia Saudita y una en el Sinaí, Nigeria, Yemen, Argelia y Jorasán (una zona en Afganistán y Pakistán)- son consideradas provincias que no se pueden perder fácilmente, porque allí su población le ha jurado lealtad a la organización (Ver Mapa $N^{0}$ 5). Esto hace pensar a su vez, según RT (Rusia Today) el Estado Islámico ve al mundo tal como se aprecia en el mapa siguiente. 
Mapa No 5

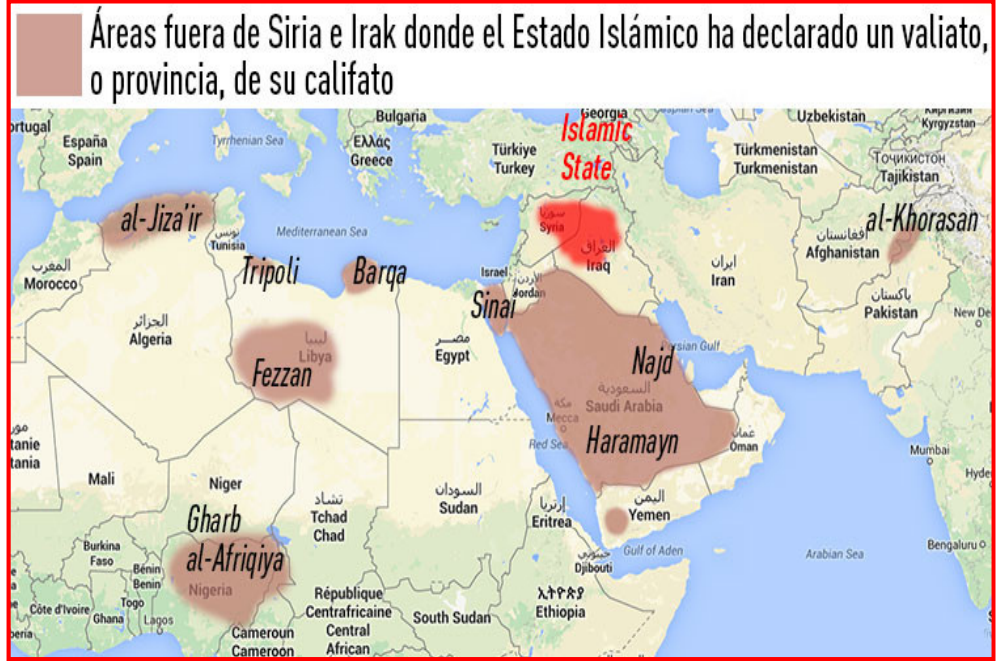

Fuente: RT (Russia Today) Canal de noticias en español

En síntesis, el califato aspira a controlar todas las regiones que alguna vez estuvieron bajo dominio árabe: Medio Oriente, el Norte de África, la península Ibérica y el sudeste de Europa (Mapa $\mathrm{N}^{\circ} 6$ ). De sus recursos y del rechazo internacional dependerá que se acerquen a su objetivo.

Mapa $N^{\circ} 6$

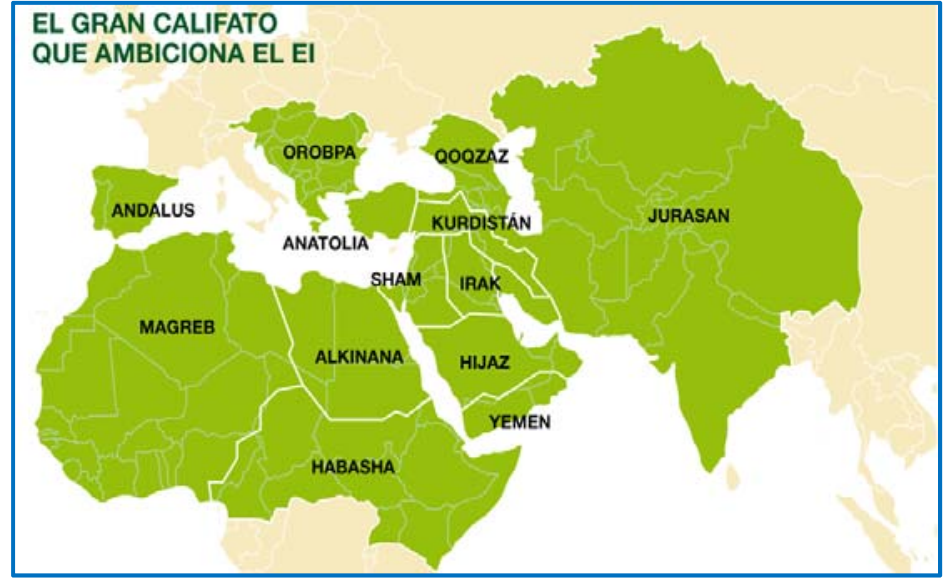

Fuente: Radiografía del Estado Islámico. En: http://www.elperiodico.com/es/graficos/internacional/radiografia-delestado-islamico-5210/

\section{Financiamiento del grupo}

Tanto en el territorio iraquí como en el sirio, el Estado Islámico utiliza tácticas crudas y repulsivas cuando se trata de luchar contra el enemigo, en este sentido, sus métodos para generar dinero y financiar sus actividades son altamente sofisticados. Su presupuesto anual se evalúa a cerca de 2 mil millones de dólares, en el que su principal fuente de ingresos es la venta de petróleo y gas de los campos que controla, la agricultura y los impuestos que recauda en su territorio. También se financia con actividades ilícitas como extorsión, tráfico de personas y contrabando de obras de arte

Publicado en formato digital: Mgter. Prof. Fernando Ariel Bonfanti. ESTADO ISLÁMICO: ¿AMENAZA PARA EL MUNDO O EL SURGIMIENTO DE UN NUEVO ESTADO? Revista Geográfica Digital. IGUNNE. Facultad de Humanidades. UNNE. Año 13. № 25. Enero - Junio 2016. ISSN 1668-5180 Resistencia, Chaco.

En: http://hum.unne.edu.ar/revistas/geoweb/default.htm 
(Hamon, 2015). Sus abundantes ingresos le sirven para reforzar el ejército, pero también para "construir" la adhesión material de unas poblaciones abandonadas por los Estados-Nación de la zona. En Irak, sin duda, la población sunnita que no ha huido prefiere el terror yihadista, al desprecio de Bagdad y la persecución y violencia de las milicias chiitas e iraníes (Rico, 2015).

La cadena de noticias internacional BBC Mundo, reconoce la existencia de seis importantes fuentes de financiamiento que tiene ISIS: 1) donaciones, 2) control del petróleo, 3) secuestros, 4) robos, saqueos y extorsión, 5) impuestos sobre minorías religiosas y 6) esclavitud.

1- Donaciones: En el medio de la guerra sectaria regional que se viene produciendo desde hace varios años entre chiíes y sunníes, los grupos fundamentalistas han recibido, en varias ocasiones miles de millones de dólares por parte de ciudadanos adinerados y diferentes entidades de países del Golfo Pérsico. Las donaciones provenientes de países como Arabia Saudí, Kuwait y Qatar han sido claves para que el ISIS creciera en armas y combatientes. Sus benefactores sunitas donaban con el fin de derrocar al presidente de Siria, Bashar al Assad, perteneciente a la secta alauí, una vertiente minoritaria del islam chií.

2- Petróleo: Este hidrocarburo es el de mayor importancia en la región, en este aspecto y teniendo en cuenta que Irak es el segundo país productor de petróleo detrás de Arabia Saudita, el Estado Islámico ha conquistado militarmente y controla varias zonas claves de la industria petrolera en el norte iraquí (ciudad de Mosul) y en el norte de Siria, desde allí han cortado el suministro de crudo a Turquía, a la vez que intentan controlar las abundantes fuentes energéticas en el Kurdistán iraquí. El negocio consiste en la venta del petróleo crudo y productos refinados a los intermediarios locales, quienes a su vez los contrabandeaban a Turquía e Irán, o los venden al gobierno sirio, generando ingresos exorbitantes que pueden oscilar entre 1 y 2 millones de dólares por día.

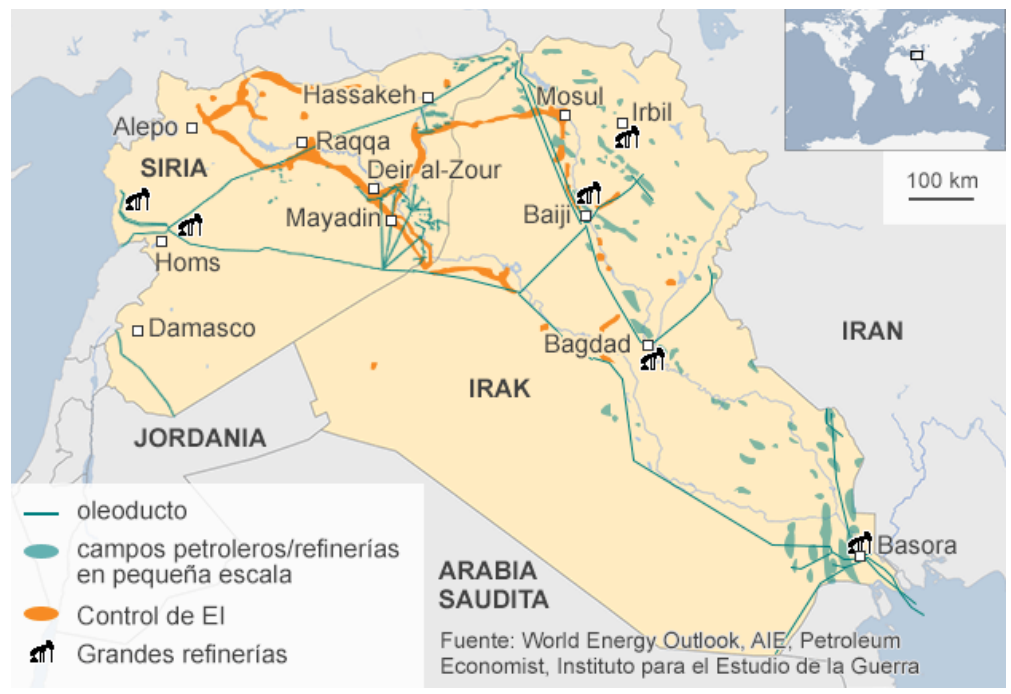

Fuente: Extraido de

http://www.bbc.com/mundo/noticias/2015/11/151118_estado_islamico_financiamiento_gch_ilm

3- Secuestro: Los secuestros también generan millones de dólares por el pago de los rescates; en este aspecto, la organización dispone de un departamento entero dedicado a los secuestros, llamado "Aparato de Inteligencia". El blanco favorito son los periodistas extranjeros en el momento exacto en que ponen un pie en las ciudades cercanas a la frontera con Siria y los soldados de la coalición internacional. La milicia radical aplica su propio sistema judicial, a veces piden millones de dólares por la liberación de un prisionero, en otros casos los sentencian a muerte y en innumerables ocasiones les aplican castigos inhumanos como torturas, amputaciones o lapidaciones.

4 -El robo, el saqueo y la extorsión: El asalto a bancos, fundamentalmente en la ciudad de Mosul, es una actividad ilícita que le genera importantes ingresos a ISIS. También se dedican a

Publicado en formato digital: Mgter. Prof. Fernando Ariel Bonfanti. ESTADO ISLÁMICO: ¿AMENAZA PARA EL MUNDO O EL SURGIMIENTO DE UN NUEVO ESTADO? Revista Geográfica Digital. IGUNNE. Facultad de Humanidades. UNNE. Año 13. No 25. Enero - Junio 2016. ISSN 1668-5180 Resistencia, Chaco. 
saquear algunas aldeas en los territorios que domina y obtiene varios millones de dólares mensuales a través de la extorsión a quienes viven en las zonas bajo su control total o parcial. Les cobran dinero a todos los que pasan por la zona, hacen negocios o simplemente viven allí, a cambio de la prestación de servicios o la "protección".

5- Impuesto sobre las minorías religiosas: Las minorías religiosas se ven obligadas a pagar un impuesto especial, llamado "jizya". En el año 2014, ni bien autoproclamaron su califato, publicaron en todas las mezquitas de la ciudad iraquí de Mosul un comunicado llamando (obligando) a los cristianos a convertirse al islam, pagar impuestos o enfrentar la muerte si no abandonaban la ciudad, de ahí el hecho de que a todas las personas en desacuerdo con este proceder no le queda alternativa que escapar y emigrar como refugiados hacia otros territorios, fundamentalmente a Europa a través del Mar Mediterráneo.

6- La esclavitud: ISIS también ha recaudado fondos mediante la venta de niñas y mujeres secuestradas como esclavas sexuales. Cuando el Estado Islámico tomó la ciudad de Sinjar (en el norte de Irak), la minoría religiosa yazidí denunció que miles de sus mujeres y niñas fueron tomadas como prisioneras y muchas fueron utilizadas como esclavas sexuales. Las conducen hasta un mercado de esclavos donde los combatientes eligen a sus mujeres.

\section{El manejo del agua podría ser una alternativa de financiamiento}

Durante el año 2015, la coalición que encabeza Estados Unidos ha bombardeado objetivos de petróleo que controla ISIS con el propósito de dañar este sistema financiero del grupo, cosa que lo ha conseguido.

De este modo, en el último tiempo se ha producido una caída significativa de los ingresos del grupo terrorista provenientes del contrabando de petróleo; a causa de esto, la organización puede cambiar su estrategia hacia tácticas de construcción del Estado, centrándose en la gestión de la infraestructura del agua para mantener su influencia en la región. En este sentido, si bien todavía no han demostrado capacidad para operar la infraestructura del agua (que es tecnológicamente intensa), sigue persiguiendo el control de presas y sistemas de agua en Irak y Siria, lo que, en el caso de ser conseguido y adecuadamente mantenido podría legitimar parcialmente su gobierno, 0 , alternativamente, ser explotado como arma (Beach, 2015).

Beach (2015) afirma que la organización recibe dinero de los empresarios de la ciudad de Raqqa "a cambio del suministro de electricidad, agua y seguridad", y a su vez cita las palabras de Michael Stephens, experto en Oriente Medio y director adjunto del centro de estudios del Instituto Real de Servicios Unidos en Qatar, cuando dice: El Estado Islámico "entiende lo poderoso que es el agua como herramienta, y no tendrá miedo de usarla", pues si consiguieran dominar esos servicios, la gente los apoyaría hasta el último segundo.

\section{Según los líderes religiosos, el terrorismo no tiene nada que ver con el Islam}

En los últimos 4 o 5 años, el terrorismo de carácter yihadista se ha convertido en el epicentro de la preocupación mundial, porque han desplegado una violencia extrema por diferentes continentes sin que, gobiernos y sociedades, encuentren la forma eficaz de enfrentarlo.

La inmensa mayoría de las personas asesinadas son miembros de la misma confesión islámica que los yihadistas intentan secuestrar, para lo cual tienen una implantación territorial en África y Oriente (Ver mapa $\mathrm{N}^{\circ} 7$ ) y desde allí se constituyen en una amenaza para la humanidad, porque quieren acabar con todos aquellos -independientemente de la religión que profesen- que no compartan con ellos los objetivos de imponer su yihad, y así lo hicieron saber durante los últimos tiempos con atentados terroristas que han causado víctimas en Beirut, Bangkok, Mogadiscio, Ciudad de Kuwait, Túnez, Ankara, Paris, etc... uniendo en el dolor a millones de ciudadanos de países muy distantes geográficamente como El Líbano, Tailandia, Madagascar, Nigeria, Mali, Francia, Dinamarca, Australia, entre otros; y en forma crónica en los territorios palestinos ocupados por la entidad sionista, que sufre el terrorismo hace ya 70 años.

Publicado en formato digital: Mgter. Prof. Fernando Ariel Bonfanti. ESTADO ISLÁMICO: ¿AMENAZA PARA EL MUNDO O EL SURGIMIENTO DE UN NUEVO ESTADO? Revista Geográfica Digital. IGUNNE. Facultad de Humanidades. UNNE. Año 13. № 25. Enero - Junio 2016. ISSN 1668-5180 Resistencia, Chaco. 
Mapa No 7

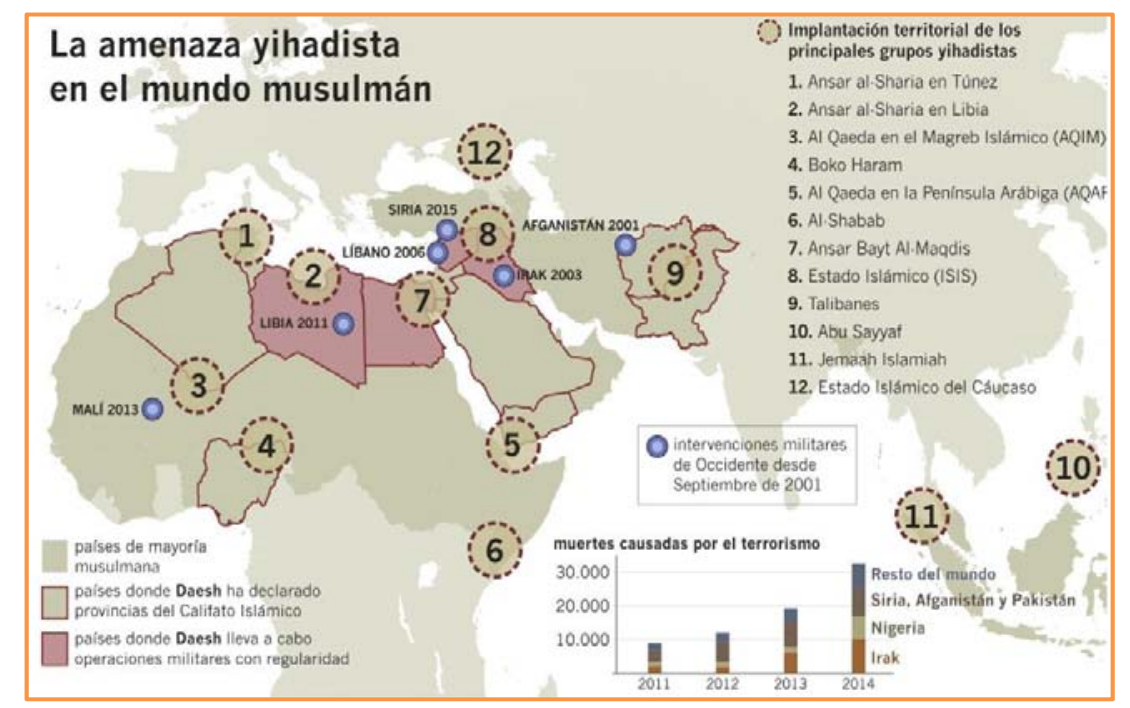

Fuente: Extraído de Alcalde, Jesús Diez. "Conciencia, firmeza y compromiso frente al odio yihadista. Capítulo 4. La Seguridad en el siglo XXI.

La masacre producida en París, en noviembre de 2015, ha sido uno de los últimos ataques yihadistas (realizados en nombre del autoproclamado Estado Islámico o Daesh, que desde 2014 se ha convertido en la principal amenaza contra la libertad y la democracia en el mundo). Este acontecimiento constituyó una prueba más de que, el Estado islámico ha coordinado muy bien una masacre terrorista desde un lugar alejado de Europa, desde donde ha controlado a su enemigo occidental, mientras sigue asesinando, de forma reiterativa y cruel, al cercano, conformado por todos aquellos a los que consideran apóstatas e infieles, que sólo merecen la muerte o vivir aterrorizados bajo la imposición violenta de la ley islámica.

Luego de este atentado, la ciudadanía tomó conocimientos de que Beirut (Líbano) se convirtió en el siniestro anticipo de la matanza terrorista en París; pocos días después se publicó la noticia de que, el derribo del avión ruso en el Sinaí el pasado 31 de octubre de 2015, se debió a una bomba de los criminales yihadistas; Nigeria sufrió un nuevo ataque de Boko Haram, el grupo más sanguinario de África; y en Malí, los secuaces de Al-Qaeda sembraron de muerte un hotel de Bamako... (Alcalde, 2015)

Evidentemente, el costo humano de la existencia del Estado Islámico es terrible; pero, por ejemplo la amenaza que representa para Estados Unidos es menor que Al Qaeda. El núcleo de este último grupo está obsesionado con el "enemigo lejano" (Occidente), en cambio lo que interesa a los yihadistas es su entorno. El Estado Islámico ve enemigos en todas partes y, aunque sus dirigentes aborrecen a Estados Unidos, la aplicación de la sharía en el califato y la expansión a las regiones vecinas son sus prioridades.

Muchos de los combatientes extranjeros (con sus familias) viajan hacia algún territorio del califato solo con pasajes de ida, ya que en su nuevo destino quieren vivir bajo la auténtica sharía, y muchos desean ser mártires. En algunos casos, aquellos que viajan en forma solitaria o en pequeños grupos y que apoyan al Estado Islámico han atacado objetivos occidentales -Ottawaa, Sidney, París, Copenhague- (Ver Mapa $N^{\circ}$ 8) para sembrar pánico. Pero los terroristas, en su mayoría, son aficionados frustrados, que no han podido viajar al califato porque les han confiscado el pasaporte. En este sentido, aunque el Estado Islámico celebre estos atentados, todavía no ha planeado ni financiado ninguno de gran envergadura, pues se ha afirmado que, por ejemplo el ataque contra la

Publicado en formato digital: Mgter. Prof. Fernando Ariel Bonfanti. ESTADO ISLÁMICO: ¿AMENAZA PARA EL MUNDO O EL SURGIMIENTO DE UN NUEVO ESTADO? Revista Geográfica Digital. IGUNNE. Facultad de Humanidades. UNNE. Año 13. № 25. Enero - Junio 2016. ISSN 1668-5180 Resistencia, Chaco.

En: http://hum.unne.edu.ar/revistas/geoweb/default.htm 
Editorial de la revista Charlie Hebdo, en enero de 2015 en París, que arrojó un saldo de 17 muertos, fue fundamentalmente una operación de Al Qaeda.

Mapa No 8

\section{La amenaza yihadista en el mundo occidental}

ataques yihadistas en suelo occidental a partir de 2001
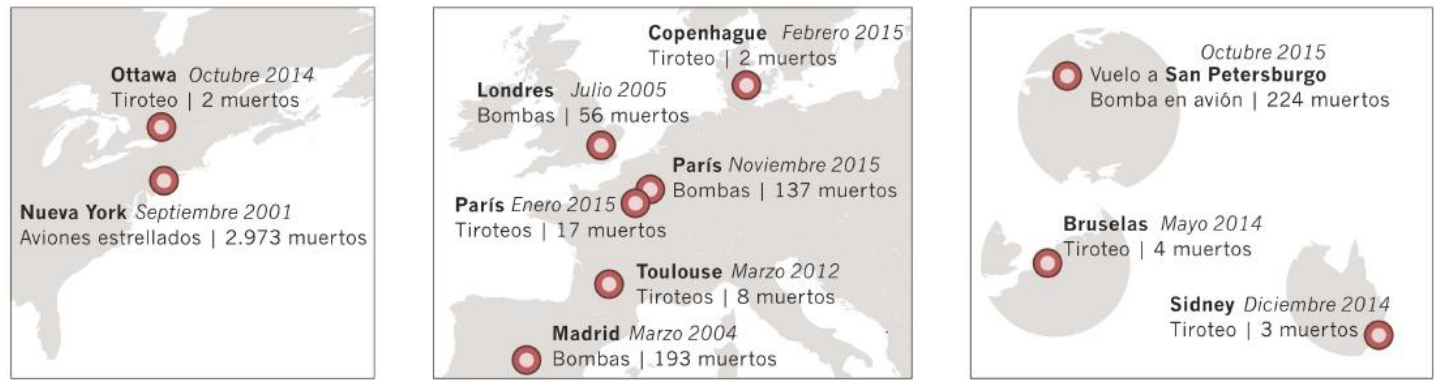

Fuente: Extraído de Alcalde, Jesús Diez. "Conciencia, firmeza y compromiso frente al odio yihadista. Capítulo 4. La Seguridad en el siglo XXI.

Como se aprecia en el esquema anterior, los últimos dos ataques terroristas han sido: la explosión del avión ruso Airbus A321 en la península egipcia del Sinaí, que acabó con la vida de 224 personas, y una cadena de atentados en París que produjo 137 muertos y más de 300 heridos.

Todos estos acontecimientos han generado que, además de la potencia norteamericana, Rusia y Francia han comenzado a desarrollar una cooperación conjunta para llevar adelante un plan de acción por mar y aire en territorio sirio para tratar de combatir con eficacia al grupo extremista y debilitar al Estado Islámico. Esta coalición es necesaria, ya que Rusia debe ser parte de la solución en Siria, aunque si todo el procedimiento -militar y de inteligencia- lo lidera la OTAN, éste último país podría quedar excluido por no ser miembro.

La contradicción aquí radica en que Moscú apoya a las fuerzas del presidente de Siria, Bashar al Assad (apoyo que constituye un ataque contra el derecho de los sirios a la libre autodeterminación política), mientras que EE.UU. persigue objetivos que poco tienen que ver con asegurar las condiciones para desarrollar un proceso político y establecer la reconciliación nacional en Siria, porque supuestamente mantienen una alianza contra el terrorismo para que gran parte del territorio sirio e iraquí estén en manos de ISIS.

Esta arremetida del gobierno de Vladimir Putin en territorio sirio ha tenido respuestas rápidas de los yihadistas, que a través de una producción cinematográfica han decretado que el próximo objetivo, en su denominada "guerra santa", sea la ciudad de Moscú.

En este sentido, y observando toda esta ola de violencia, hacia fines de 2015, los principales líderes espirituales de Islam, han publicado cartas con el objetivo principal de mostrarle al mundo la verdadera cara del Islam alejada de todos los estereotipos, una cara que no esté teñida del enfoque demonizador que occidente ha hecho de esta cultura en los últimos años y que ha generado una ola general de islamofobia, radicando allí el origen de la violencia en una política agresiva y hegemónica de las grandes potencias occidentales y sus aliados incondicionales, que induce a que gran parte de la civilización mundial asimile al Islam con el terrorismo. En verdad, el Islam no tiene nada que ver con el terrorismo y menos aún con las interpretaciones de grupos que hacen de la atrocidad su forma de actuar, surgidos, avalados, financiados y apoyados por las potencias occidentales, especialmente Estados Unidos, que a través de estos movimientos busca ampliar su grado de influencia en todos los rincones del planeta.

Publicado en formato digital: Mgter. Prof. Fernando Ariel Bonfanti. ESTADO ISLÁMICO: ¿AMENAZA PARA EL MUNDO O EL SURGIMIENTO DE UN NUEVO ESTADO? Revista Geográfica Digital. IGUNNE. Facultad de Humanidades. UNNE. Año 13. № 25. Enero - Junio 2016. ISSN 1668-5180 Resistencia, Chaco. 


\section{Consideraciones Finales}

Desde los ataques del 11 de septiembre del año 2001, Estados Unidos asumió un papel en calidad de víctima y acentuó en el inconsciente de la comunidad internacional la "islamofobia". Al respecto, un artículo titulado "Choque de Civilizaciones", publicado en 1993 por el politólogo norteamericano Samuel Huntington, afirmaba que los conflictos entre las naciones pasarían de tener carácter político o ideológico, a tener como motivo las diferencias entre grupos de civilizaciones con criterios distintos. De esta manera, este conflicto podría tener como respuesta el hecho de que la religión oriental, que por siglos ha sido conservadora, fundamental y radical en sus prácticas, se interponga ante el imaginario liberal y modernista del occidente estadounidense y europeo que los intenta colonizar en búsqueda de sus intereses personales.

La serie de manifestaciones de carácter popular y político que se sucedieron en la región árabe desde inicios del 2011, conocidas como "primavera árabe", y que condujeron a la caída de las dictaduras en Túnez y Egipto, al reforzamiento de la violencia en Yemen y a la guerra civil en Libia, ha dejado como consecuencia el incremento de la inestabilidad regional tras el inicio de una pugna de poder en la mayoría de los países afectados.

En el caso particular de Irak, ya existía una grieta entre las autoridades tradicionales sunnitas desde la ocupación estadounidense en su territorio, con predominio de corrupción y deficiente situación económica. Por el lado de Siria, los reclamos de justicia, libertad y reformas terminaron en una guerra civil que enfrentó desde 2011, a las Fuerzas Armadas del gobierno del presidente sirio, Bashar Al-Asad contra grupos armados rebeldes de diversa índole, conocidos en occidente como la oposición siria. Esta grave problemática regional, a la que también se le unió la crisis de legitimidad religiosa, dejó un vacío que el Estado Islámico supo explotar desde su conformación en 2014 y que permitió su consolidación como un proto-estado.

La autoproclamación de su califato islámico en territorio sirio-iraquí fue el primer paso que ha dado esta organización, y a partir de ahí su principal deseo ha sido la aplicación en forma estricta con su propio gobierno y sus propias instituciones- de la sharía o ley islámica en un territorio específico. El Estado Islámico logró establecer una sinergia paradójica entre los problemas locales y los desafíos del escenario internacional, diferenciándose de Al-Qaeda, pues permite a grupos tribales o minoritarios acceder a una forma de universalidad, integrándolos en una yihad global contra todos aquellos considerados "malos creyentes" e "infieles", que son, por un lado, los musulmanes que siguen apoyando los regímenes establecidos en el mundo árabe, y por otro lado, las democracias occidentales a quienes consideran como las principales responsables de las injusticias cometidas contra los musulmanes desde la época colonial.

Por otra parte, y reflexionado acerca de las palabras de Martín (2015), el gran líder de toda esta organización islámica, Al Baghdadi, se equipara a los grandes califas de la historia musulmana y ha hecho algo que ni siquiera se atrevió a hacer Bin Laden; proclamar el califato y reclamar el liderazgo político y religioso del Islam, que está en poder de Arabia Saudí desde la extinción del califato otomano en 1924. Dentro de esa búsqueda de la gloria el objetivo es claro: apoderarse de Bagdad (ciudad donde los grandes califas siempre tuvieron su capital); Mosul es solo un paso, es decir que la legitimidad le llegará el día que puedan instalarse en la actual capital de Iraq.

Particularmente en territorio sirio, la población civil siente que nadie los defiende, y en esa desesperación pareciera ser que Occidente solo les da dos opciones: el régimen de Bachar el Assad (presidente del país) o el Estado Islámico. Ante la seguidilla de persecuciones y asesinatos que han sufrido muchos musulmanes en el mundo sin que nadie los defendiera, aparecen los seguidores del califa Al Baghdadi, que de a poco comenzaron a mostrarse como la única opción clara. El Estado Islámico sabe exactamente lo que es, lo que está haciendo y hacia dónde va. Y esto tiene sentido para la gente desprotegida, que busca salir de su confusión, y en muchos casos esto les permite sumar adeptos.

Lo que no debe olvidarse es que las políticas norteamericanas aplicadas en Siria han sido las que llevaron al ascenso al Estado Islámico, ya que fueron el resultado de una toma de decisión explícita y consciente; pues el mismo gobierno que en su momento se dedicó a luchar contra Al-

Publicado en formato digital: Mgter. Prof. Fernando Ariel Bonfanti. ESTADO ISLÁMICO: ¿AMENAZA PARA EL MUNDO O EL SURGIMIENTO DE UN NUEVO ESTADO? Revista Geográfica Digital. IGUNNE. Facultad de Humanidades. UNNE. Año 13. No 25. Enero - Junio 2016. ISSN 1668-5180 Resistencia, Chaco. 
Qaeda, posteriormente ha reforzado y armado a Al-Qaeda en Siria. Así pues, dicho en otras palabras: EEUU creó todas las circunstancias adecuadas para el surgimiento del Estado Islámico y su posterior ascenso, quizá para demostrarle al mundo su gran poderío militar.

El Estado islámico opera también a través de provocaciones crueles y sistemáticas que responden a un listado consciente de todo lo que puede provocar reacciones emocionales y fomentar la guerra. Frente a la coalición en su contra, los yihadistas han logrado multiplicar sus privilegios, aliándose con grupos salafistas que cada día juran su lealtad al califato autoproclamado de Abu Bakr al Baghdadi -desde Boko Haram en Nigeria hasta ex-combatientes de Al Qaeda en Yemen, pasando por varios grupos insurgentes en Libia y en el Sinaí-. Y no le importa mucho si pierde algo del terreno conquistado en Kobané (Siria) o en Tikrit (Iraq), ya que por definición no tiene fronteras

En definitiva, su provocación a occidente ha permitido que el presidente norteamericano Barak Obama fije una meta de diez años para acabar con ellos; pero una guerra de este tipo no se gana solo con bombardeos aéreos, también se deben proponer soluciones políticas a los pueblos y comunidades de la región. La única manera de luchar contra movimientos de interpretación herética es con movimientos suníes que aseguren la paz social. Hay que crear una alternativa suní en Iraq que se aparte de esa interpretación radical del Islam. La gente no apoya al Estado Islámico. Apoya la seguridad que éste les otorga. Si hay otro movimiento suní que les ofrezca alternativas, lo respaldarán. (Martín, 2015)

Efectivamente, estamos hablando de un grupo que realiza sangrientos atentados, controla una gran extensión de territorio, tiene una estructura interna bien organizada, está bien financiado y maneja perfectamente la comunicación y la publicidad. Todos ellos son elementos necesarios para apuntar que el Estado Islámico es un enemigo al que los gobiernos se van a enfrentar durante mucho tiempo; por lo tanto habría que ver más adelante si todas sus pretensiones logran cumplirse, aunque para ser considerado estado, deberá tener legitimidad internacional (y está lejos de lograrlo).

Para finalizar, solo queda por decir que el Estado Islámico representa actualmente la mayor amenaza de terrorismo en el mundo, no solo por sus recientes actuaciones y amenazas a países europeos como Alemania, Francia y Bélgica, sino por la acumulación de tantos años de odio y rencor sembrados por Occidente. 


\section{Bibliografía}

1) ALBA RICO, Santiago (2015) "El Estado islámico y la revolución negativa". El Diplo. Edición N 193 - Julio de 2015. En: https://es.scribd.com/doc/290179411/el-diplo-2002376

2) ALCALDE, Jesús Diez. "Conciencia, firmeza y compromiso frente al odio yihadista. Capítulo 4. La Seguridad en el siglo XXI. En: http://elordenmundial.com/wpcontent/uploads/2015/12/Articulo191.pdf

3) BBC MUNDO. Cadena de Noticias. "Del petróleo a la esclavitud: las 6 principales fuentes de financiamiento de Estado Islámico". Noticia publicada el 19 de noviembre de 2015 En:http://www.bbc.com/mundo/noticias/2015/11/151118_estado_islamico_financiamiento_gch_il $\mathrm{m}$

4) BEACH Allyson (2015) ¿Cuál es el arma más mortífera del Estado Islámico? Artículo publicado el 8 de Mayo de 2015. En: https://actualidad.rt.com/actualidad/174273-agua-arma-estadoislamico-ei

5) BELTRAME, Florencia (2009) "La construcción occidental de la figura del enemigo islámico. La nueva hegemonía de Estados Unidos". En: APOSTA. Revista de Ciencias Sociales. № 42, Julio, Agosto y Septiembre 2009. Universidad de Buenos Aires. Disponible en: http://www.apostadigital.com/revistav3/hemeroteca/beltrame1.pdf

6) BRIEGER, Pedro (2006) "Qué es Al Qaeda. Terrorismo y violencia política". Ed. Capital Intelectual, Buenos Aires.

7) El Periódico Internacional. "Radiografía del Estado islámico". Disponible en: http://www.elperiodico.com/es/graficos/internacional/radiografia-del-estado-islamico-5210/

8) FREEMAN, Robert (2014) "Paso a paso: cómo EE.UU. creó al Estado Islámico. Publicado: 23 sep 2014. Disponible en: https://actualidad.rt.com/actualidad/view/141159-eeuu-creo-estadoislamico

9) HAMON, Alexandre (2015) "ISIS: un proto-Estado armado para durar". En: http://www.elmostrador.cl/noticias/mundo/2015/07/24/isis-un-proto-estado-armado-para-durar/

10) HUNTINGTON, Samuel (1993) “¿Choque de Civilizaciones?". Ensayo disponible en: https://www.uam.es/personal_pdi/derecho/acampos/Huntington_ChoqueCivilizaciones.pdf

11) LUIZARD, Jean-Pierre (2015) “La emergencia del Estado Islámico. Claves geopolíticas, historia y clivajes confesionales". En: Revista Nueva Sociedad N²57, mayo-junio 2015.

12) MARTín, Javier (2015) "Estado islámico. Geopolítica del caos". Ed. Catarata, Madrid.

13) MARTíN MUÑOZ, Gema (2003) "Iraq. Un fracaso de Occidente (1920-2003)". Ed. Tusquets, Barcelona, España.

14) NAPOLEONI, Loretta (2015) El fénix islamista: el Estado Islámico y el rediseño de Oriente Próximo Ediciones Paidós, Barcelona, 2015

15) PÉREZ VENTURA, Juan (2014) "Estado Islámico, el nuevo enemigo". En: http://elordenmundial.com/regiones/oriente-medio/estado-islamico-el-nuevo-enemigo/

16) RAMONET, Ignacio (2005) "Irak. Historia de un desastre". Ed. Debate, Barcelona, España.

17) RT (Russia Today) Canal de noticias en español. Disponible en: https://actualidad.rt.com/actualidad/view/141159-eeuu-creo-estado-islamico

18) TAIBO, Carlos (2003) "Cien preguntas sobre el nuevo desorden. Una mirada lúcida sobre la globalización y sus consecuencias". Madrid: Suma de Letras.

Publicado en formato digital: Mgter. Prof. Fernando Ariel Bonfanti. ESTADO ISLÁmICO: ¿AMENAZA PARA EL MUNDO O EL SURGIMIENTO DE UN NUEVO ESTADO? Revista Geográfica Digital. IGUNNE. Facultad de Humanidades. UNNE. Año 13. No 25. Enero - Junio 2016. ISSN 1668-5180 Resistencia, Chaco.

En: http://hum.unne.edu.ar/revistas/geoweb/default.htm 